\title{
Spiritualitas Gembala Sidang Dan Implikasinya Bagi Keteladanan Pembinaan Warga Gereja
}

\section{Fauduzanolo Boololo, Gusmayeni Telaumbanua, Riska Fitriani, David Eko Setiawan}

\author{
Sekolah Tinggi Teologi Tawangmangu \\ fauduzanolo@gmail.com \\ yenni.thelau@gmail.com \\ riskafi722@gmail.com \\ Davidekosetiawan14217@gmail.com,
}

\begin{abstract}
This article will internalize existing data about the degeneration of values, the purpose and meaning of being a pastor, so that many Church members experience doubts and question the purity and spirituality of God's servants or in the real congregation pastor. The spirituality of the Pastor is the spiritual life or relationship with Christ that is seen through his actions, emotions and attitudes. Where not only vertically to God but will be evident from his actions to others. In this study, it describes the spirituality of the Council Shepherd and its implications for the exemplary formation of Church members. This study uses the literature method to answer existing problems. This problem is related to the question, What is the impact of the spirituality of the Council Pastor and its implications for the exemplary formation of Church members? The conclusion of this research is that if the servant of God does not live his spirituality, this implies that he will find servants of God who cannot be trusted. In addition, it will have implications for members of the Church.
\end{abstract}

Keywords: Spirituality, Pastor, Community Development of the Church

\begin{abstract}
Abstrak
Artikel ini akan menginternalisasikan data-data yang ada tentang kemorosotan nilai, Tujuan dan makna menjadi Gembala Sidang, sehingga warga Gereja banyak yang mengalami keraguraguan dan mempertanyakan kemurnian dan spiritualitas hamba Tuhan atau dengan istilah Gembala Sidang yang sebenarnya. Spiritualitas Gembala Sidang adalah kehidupan rohani atau hubungan dengan Kristus yang terlihat melalui tindakan, emosi dan sikap kehidupannya. Dimana bukan hanya secara vertikal kepada Tuhan melainkan akan nyata dari tindakannya kepada sesama. Dalam penelitian ini menjelaskan mengenai spiritualitas Gembala Sidang dan implikasinya bagi keteladanan pembinaan warga Gereja. Penelitian ini menggunakan metode kepustakaan untuk menjawab permasalahan yang ada. Permasalahan tersebut terkait dengan mempertanyakan, Apa dampak spiritualitas Gembala Sidang dan impilikasinya bagi keteladanan pembinaan warga Gereja ?. Kesimpulan dari penelitian ini adalah Jika hamba Tuhan tidak menghidupi spiritualitasnya, maka akan berimplikasi akan menemukan hamba Tuhan yang tidak dapat dipercaya. Selain itu akan berimplikasi kepada warga Gereja.
\end{abstract}

Kata Kunci: Spiritualitas, Gembala Sidang, Pembinaan Warga Gereja 


\section{PENDAHULUAN}

Seorang Gembala Sidang harus memiliki spiritualitas yang lebih baik daripada spiritualitas Jemaat. Dalam sebuah Gereja jemaat merupakan suatu hal yang penting bukan untuk diabaikan melainkan untuk dibina, diajar supaya iman/spiritualitas jemaat dapat bertumbuh. Maka, pembinaan warga Gereja sangatlah penting. Berbicara tentang PWG adalah usaha untuk membina warga Gereja menjadi lebih baik dari sebelumnya yang berpusat pada Kristus Tuhan, dan Alkitab menjadi pedoman penuntunnya dan merupakan proses untuk menghubungkan jemaat dengan Firman Tuhan melalui pembinaan, pembimbingan dan pengajaran yang mendewasakan dalam Kristus melalui Roh Kudus. Oleh sebab itu, Gereja sebagai presentasi Tuhan Yesus diharapkan oleh umat, bahkan oleh dunia untuk menjadi bagian yang penting dalam pembinaan Iman/Spiritualitas Jemaat. "Spiritualitas" adalah kerohanian, kehidupan rohani, atau disiplin rohani, atau hubungan pribadi kepada Allah.

Menurut Pailang, memberikan lingkup bagi kehidupan spiritualitas sebagai satu upaya yang terus menerus untuk mendemonstrasikan hidup yang berarti atau bermakna dengan menjaga dan memelihara iman serta faktor-faktor yang berkaitan dengan seseorang atau dalam komunitas supaya dapat mengambil sikap dan keputusan dalam realitas hidup ditengah-tengah tantangan dalam kehidupan. ${ }^{1}$ Menurut Djadi, yang mengatakan bahwa spiritualitas seseorang adalah mengankut kehidupan rohani. ${ }^{2}$ Seorang pelayan Kristus atau dengan istilah Gembala Sidang terkait dengan spiritualitasnya adalah kehidupan rohani atau disiplin rohani, atau hubungan pribadi dengan Allah yang dilakukan tanpa berhenti oleh seorang pelayan Kristus atau orang yang terpanggil untuk melayani Tuhan dalam seluruh aspek kehidupannya, baik secara formal maupun nonformal. ${ }^{3}$ Menurut Hasahatan, Bonnarty.S dalam penelitian yang mengatakan bahwa spiritualitas dapat digambarkan sebagai keberadaan titik Imani seseorang yang terpancar jelas dari kehidupannya, baik menyangkut hubungannya dengan Allah, orang lain maupun alam yang disekitarnya. ${ }^{4}$

Dari semula istilah Gembala telah ada mulai dari penciptaan di Taman Eden setelah Allah menjadikan manusia pertama, yaitu Adam dan Hawa. Kemudian Allah berperan dan bertanggung jawab kepada manusia sebagai Gembala. Pete Anggu mengatakan "Allah sang pencipta pada hakikatnya adalah Gembala yang pelindung, pemelihara, penjaga umat-Nya. ${ }^{5}$ Seorang pelayan Tuhan dalam Gereja merupakan suatu bentuk pembinaan yang dilakukan

${ }^{1}$ H. S. I. B. P. Pailang, "Membangun Spiritual Remaja Masa Kini Berdasarkan Amsal 22 : 6," Jaffray 10, No. 1 (2012): 59.

2 Jermia Djadi, "Spiritualitas Seorang Pelayan Kritus," Jaffray 10, No. 1 (2012): 110.

3 Hasahatan Hutahaean, Bonnarty Steven Silalahi, and Linda Zenita Simanjuntak, "Spiritualitas Pandemik: Tinjauan Fenomenologi Ibadah Di Rumah," Evangelikal: Jurnal Teologi Injili dan Pembinaan Warga Jemaat 4, no. 2 (2020): 234.

${ }^{4}$ Ibid.

${ }^{5}$ Peter Anggu, Etika Penggembalaan (Makassar: STT Jaffray, 2003), 46. 
oleh pihak Gereja kepada warga Gereja agar mereka dapat melaksanakan tugas dan penggilan Tuhan. Setiap bentuk pembinaan yang dilakukan oleh Gembala Sidang melalui pelayananpelayanan merupakan suatu bentuk usaha dari Gereja untuk membawa umat Allah menjadi dewasa secara spiritualitas, agar melalui setiap proses pembinaan akan mengalami perubahan diri yang terus-menerus, setiap warga Gereja mau dan mampu bersaksi, bersekutu dan melayani ditengah-tengah Gereja dan masyarakat.

Spiritualitas Gembala Sidang menjadi topik yang sangat penting dan menarik untuk dibahas melihat banyaknya data tentang kemorosotan nilai, tujuan dan makna dari mereka. Ada banyak skandal kekuasaan, seks dan keuangan yang melibatkan beberapa dari ${ }^{6}$ mereka membuktikan bahwa kemerosotan itu nyata. ${ }^{7}$ Dermot menyoroti beberapa skandal tersebutn seperti, pada tahun 1980 pengkhotbah TV di Amerika telah menipu serta menyalahgunakan uang dari pada pendukungnya untuk memuaskan nafsu seks mereka. Kemudian pada tahun 1990 juga ditemukan skandal pedofilia di Gereja Katholik Roma yang melibatkan para imam mereka. Bahkan akhir-akhir ini kemorosotan tersebut mulai berdampak pada Gereja dengan dibuktikan semakin maraknya para pemimpin Gereja atau yang dikenal dengan istilah Gembala Sidang menerima perceraian dianggap menjadi solusi konflik pernikahan, pengejaran kekayaan bahkan status untuk kepentingan diri sendiri. ${ }^{8}$

Dari data yang diperolah diatas, degradasi nilai, tujuan dan makna Gembala Sidang merupakan sebuah kenyataan. Sehingga warga Gereja/Jemaat mulai meragukan spiritualitas dan kemurnian Gembala Sidang. Dari pengertian diatas penulis dapat mendefinisikan bahwa spiritualitas adalah keadaan rohani/iman seseorang yang dapat dilihat, dirasakan dan diteladani oleh orang-orang sekitarnya, dalam hal disiplin Doa, yang memiliki pengaruh yang besar dalam bagi warga Gereja.. Dari latar belakang diatas maka yang menjadi pokok masalah yang akan dibahas dalam tulisan ini, yaitu: Pertama, Apa dampak spiritualitas Gembala Sidang dan impilikasinya bagi keteladanan PWG?. Kemudian yang menjadi tujuan penulisan, yaitu: Pertama, Untuk mengetahui atau menggali dampak dari Spiritualitas Gembala Sidang dan impilikasinya bagi keteladanan PWG?

\section{METODE PENELITIAN}

Penelitian ini menggunakan metode kepustakaan. Penelitian kepustakaan adalah kegiatan penelitian yang dilakukan dengan cara mengumpulkan informasi dan data dengan bantuan berbagai macam material yang ada di perpustakaan seperti referensi, hasil penelitian

${ }^{6}$ G. R. Mc Dermot, Mengenali12 Tanda Kerohanian Sejati, ed. Terj. Suryadi (Yogyakarta, 1995), 16.

7 David Eko Setiawan and Anton Ishariyono, "Hakikat Spiritualitas Pelayan Kristus Dan Implikasinyabagi Hamba Tuhan Masa Kini” 2, no. 2 (2020): 117.

8 E. W. Iqaq, "Pemimpin Sebagai Gembala," Jurnal Jaffray 12, No.1 (2014): 27.

163 | Copyright $@$ 2021, CARAKA, ISSN 2722-1407 (Cetak), 2722-1393 (Online) 
sebelumnya, yang sejenis, artikel, catatan, serat berbagai jurnal yang berkaitan dengan masalah yang akan dipecahkan. ${ }^{9}$ Penulis akan menghimpun informasi yang relevan dengan pembahasan tentang spiritualitas Gembala Sidang sebagai implikasi keteladanan Pembinaan Warga Gereja (PWG), serta membangun relasi secara Alkitabiah. Melakukan pecarian sumber-sumber yang dibutuhkan, baik berupa buku-buku, artikel-artikel pada jurnal yang berkaitan dengan topik tersebut, serta sumber-sumber tertulis lainnya baik tercetak maupun yang dipublikasikan di internet. Sehingga pembahasan lebih berfokus mengenai Spiritualitas Gembala Sidang dan impliksainya bagi keteladanan PWG. Berdasarkan tujuan penulisan bahwa dengan penelitian ini akan menjawab bahwa spiritualitas Gembala Sidang dan implikasinya bagi keteladanan pembinaan warga Gereja dan akan menjelaskan bagaimana Gembala Sidang yang baik.

\section{HASIL DAN PEMBAHASAN \\ Pengertian Spiritualitas dan Gembala}

"Spiritualitas" adalah kerohanian, kehidupan rohani, atau disiplin rohani, atau hubungan pribadi kepada Allah. Secara terminologis, spiritualitas berasal dari kata "spirit". Dalam literature agama dan Spiritualitas, spirit memiliki dua makna substansial, yaitu: pertama, Karakter dan inti dari jiwa-jiwa manusia, yang masing-masing berkaitan, serta pengalaman dari keterkaitan jiwa-jiwa tersebut yang merupakan dasar utama dari keyakinan spiritual. "Spirit" merupakan bagian terdalam dari jiwa, dan sebagai alat komunikasi atau saran yang memungkinkan manusia untuk berhubungan dengan Tuhan. Kedua, "spirit" mengacu pada konsep bahwa semua "spirit" yang saling berkaitan merupakan bagian dari sebuah kesatuan (consciousness and intellect) yang lebih besar.

Dalam jurnal yang ditulis oleh David Eko Setiawan \& Anton Ishariyono yang berjudul: "Hakikat Spiritualitas Pelayan Kristus Dan Implikasinya Bagi Hamba Tuhan Masa Kini" Spiritualitas Kristen menurut Tanujadja mengatakan bahwa spiritualitas sebagai keberadaan seseorang yang tahu bagaimana ia seharusnya berelasi dengan sesama, diri sendiri, dan ciptaan lain, serta hidup berdasarkan pengetahuan tersebut. ${ }^{10}$

Esensi dari spiritualitas, yaitu bukan hanya tingkat pemahaman tentang Tuhan, melainkan implikasi kehidupan yang mengenjewantahkan ajaran Tuhan dalam sikap dan perilakunya setiap hari. ${ }^{11}$ Disini tugas dari agama (Gereja) untuk dapat memberdayakan jemaat, agar mampu meningkatkan spiritualitasnya., sebagai ketahanan iman dalam

\footnotetext{
${ }^{9}$ Milya Sari and Asmendri, "Penelitian Kepustakaan (Library Research) Dalam Penelitian Pendidikan IPA," Penelitian Kepustakaan (Library Research) dalam Penelitian Pendidikan IPA 2, no. 1 (2018): 44.

${ }^{10}$ Setiawan and Ishariyono, 116.

${ }^{11}$ Fibry Jati Nugroho, "Gereja Dan Kemiskinan :” 3 (2019): 100.
} 
meningkatkan presistensi dan eksistensinya dalam memperjuangkan iman ditengah realitas sosial yang ada. ${ }^{12}$

Douglas mencoba mengertikan kata Gembala secara harfiah, yang mengacu pada zaman dulu dan sekarang, yaitu suatu tugas yang mengemban panggilan dengan banyak tuntutan, dan penggilan itu setua panggilan Habel (Kej 4;2). Secara teologis, istilah Gembala menunjuk pada tindakan perawatan dan pemeliharaan yang dilakukan oleh seorang secara intensif yang tidak mengenal waktu maupun situasi dan tidak dapat diwakili oleh pribadi lain. $^{13}$

Gembala adalah penjaga kawanan ternak. Dari kata dasar "menggembalakan" adalah kata "Gembala" di dalam KBBI dijelaskan bahwa kata "Gembala" adalah sebagai penjaga atau memelihara makhluk hidup. Sedangkan yang dimaksud dengan kata "menggembalakan" ialah menjaga dan memelihara binatang (terutama ketika binatang-binatang itu sedang dipadang rumput, dan lain sebagainya). ${ }^{14}$ Menurut Howard Rice kata "Gembala dalam bahasa latin ialah pastor dan dalam bahasa Indonesia diterjemahkan pendeta, juga merupakan sebutan bagi imam Gereja Katolik Roma". ${ }^{15}$ Menurut Poerwadarminto, Gembala ada dua arti secara harafiah kata "Gembala" memiliki arti "penjaga atau pemelihara binatang ternak", secara rohani berarti "penjaga keselamatan umat Nasrani atau Pembina Warga Gereja". ${ }^{16}$ Elrath Billy Mathias dalam Ensiklopedia Alkitab Praktis memaparkan bahwa: "Di zaman Alkitab Gembala adalah pemelihara domba, suatu pekerjaan yang dapat dilakukan oleh kaum pria maupun wanita baik tua maupun muda, meskipun tugas itu cukup berat pencapaian yang statis menuju keserupaan dengan Kristus. ${ }^{17}$

Satu eksistensi kerohanian yang akan terlihat dari ekspresi spiritualitasnya dalam sehari-hari, dalam segala situasi kepada Keluarga, lingkungan, bangsa-bangsa dan terhadap Gereja tentunya. Sebab mengukur spiritualitas ke-Kristenan itu lebih merupkana sebuah perjalanan yang dinamis, bukan pencapaian yang statis menuju keserupaan dengan Kristus, terlebih Gembala Sidang menjadi teladan atau contoh bagi Jemaat yang dipimpin dalam sebuah Gereja.

\section{Spiritualitas Gembala Sidang}

Spiritualitas seorang Gembala Sidang sangat menentukan untuk mempengaruhi pertumbuhan rohani jemaat. Sikap terhadap Tuhan dan masyarakat dalam melakukan segala

\footnotetext{
${ }^{12}$ Hutahaean, Silalahi, and Simanjuntak, 234"

13 Arozatulo Telaumbanua, "Peran Gembala Sidang Sebagai Pendidik Dalam Pertumbuhan Rohani Jemaat," FIDEI: Jurnal Teologi Sistematika dan Praktika 2, no. 2 (2019): 362.

${ }^{14}$ Kamus Besar Bahasa Indonesia, (Jakarta: Departemen Pendidikan Nasional, 2008), 458.

${ }^{15}$ Rice Howard, Management Umat (Bandung: Yayasan Kalam Hidup, 2006), 19.

${ }^{16}$ WJS Purwodarminto, Kamus Umum Bahasa Indonesia (Jakarta: Yayasan Kalam Hidup, 1992), 156.

${ }^{17}$ Billy Matheas Elrath, Ensiklopedia Alkitab Praktis (Bandung: Yayasan Kalam Hidup, 1978), 40.
} 
aktivitas yang dilakukan sehingga orang mengenal kehidupannya sendiri dengan sikap yang dilihat oleh orang lain baik atai tidak baik dalam hal kerohaniannya atau memiliki spiritualitas yang baik. Aspek kehidupan Gembala dalam beraktivitas/berinteraksi dan lelayani pekerjaan sendiri di dalam Gereja untuk mendapatkan kesatuan dalam jemaat mengenai sikap Gembala Sidang terhadap kualitas pertumbuhan kerohanian. Sikap spiritualita Gembala Sidang sebagai kunci untuk pertumbuhan spiritualitas jemaat sama seperti Yesus adalah gembala yang memimpin kawanan domban-Nya membimbing, menyegarkan serta menuntun.

Sikap rendah hati disertai kasih, kepedulian, simpati/empati, tanggung jawab, dan memiliki rasa cinta terhadap jemaat yang rela berkorban untuk meningkatkan kerohanian Jemaat disetiap aspek penggembalaan yang selalu memperhatikan Jemaat dalam situasi daan kondisi Gereja. Agung Wibisan mengatakan, Kristus memberikan teladan bahwa kita hidup bukan untuk diri kita sendiri, kepentingan diri sendiri, keluarga kita sendiri, tetapi juga dengan jelas bahwa lingkungan Gereja dan lingkaran pelayanan Gereja adalah memiliki prioritas yang sudah diatur oleh Tuhan mendahulukan orang lain dan melayani orang lain memperlihatkan kepada dunia memberikan pelayanan terbaik. ${ }^{18}$

Sularso Sopater mengatakan bahwa kepemimpinan pelayanan adalah cara atau gaya hidup pemimpin yang menyikapi, dan memperlakukan yang dipimpin bukan sebagai objek, apalagi sekedar alat untuk kepentingan dirinya, melainkan sebagai subjek. Sikap dan perlakuan itu setidaknya memiliki tiga, yaitu: pelayanan pemimpin Gereja kepada warga Gereja itu tetap terpelihara, Pemimpin Gereja bersedia berkorban dalam artian tidak mementingkan diri sendiri, dan menumbuhkan pelayanan tidak hanya berfokus untuk diri sendiri karena hal yang terpenting adalah pertumbuhan iman jemaat. Berkorban itu pada hakikatnya adalah merelakan sesuatu atau bagian yang paling penting dalam hidup ini sebagai tumbal demi orang lain yang menjadi tujuan pengorbanan itu. Sikap dan tindakan berkorban untuk keselamatan warga Gereja, juga meneladani pada Tuhan Yesus Kristus. ${ }^{19}$

\section{Sifat-sifat Gembala Sidang}

Bakat menjadi seorang Gembala Sidang adalah karunia daripada Allah yang tidak bisa dibuat-buat oleh manusia. Ada beberapa sifat-sifat menjadi gembala sidang yang baik dan yang benar, ${ }^{20}$ yaitu: Pertama, kesanggupan untuk mengasihi semua orang tanpa membedabedakan, seorang Gembala Sidang yang benar adalah seorang yang mengasihi semua orang; Kedua, Gembala yang baik mengasihi domba-dombanya, Gembala yang mempunyai kasih

\footnotetext{
1998), 153-154.

${ }^{20}$ Robert Cowles, Gembala Sidang, 5th ed. (Bandung: Yayasan Kalam Hidup, 2000), 7.
}

${ }^{18}$ Agung Wibisana, Crist Centered Church (Bandung: Gereja perpustakaan Kristus, 2016), 231.

${ }^{19}$ Sularso Sopater, Kepemimpinan Dan Pembinaan Warga Gereja (Jakarta: Yayasan Wahana Dharma, 166 | Copyright $\odot$ 2021, CARAKA, ISSN 2722-1407 (Cetak), 2722-1393 (Online) 
daripada Allah bagi anggota-anggotanya akan sangat memperhatikan mereka (kepedulian) (Yoh 10:11-16); Ketiga, Yesus juga mengatakan Gembala yang baik menyerahkan nyawanya bagi domba-dombanya; Keempat, seorang gembala yang benar juga harus berani dan tekun tanpa bermalas-malasan, ia tidak akan melarikan diri apabila serigala datang, dalam artian seorang Gembala Sidang harus bisa menghadapi masalah yang terjadi; Kelima, Gembala yang baik menurut Tuhan Yesus, ialah gairah untuk menginjili dalam artian memiliki beban bagi jiwa-jiwa yang belum terselamatkan atau yang belum mengenal Yesus, tidak mementingkan diri sendiri, tetap setia dalam perkara, mempunyai semangat untuk menginjil. ${ }^{21}$

Menurut M. Bons-Storm, ada sifat-sifat seorang Gembala Sidang yang baik dan yang benar, yaitu: Pertama, seorang Gembala adalah seorang yang mengenal Yesus Kristus, sehingga ia dapat meniru tindakan Yesus dalam penggembalaan dan sebagai wakil Tuhan untuk warga Gereja. Kedua, seorang Gembala harus mempunyai sifat suka bergaul dengan orang lain dalam hal, yaitu: a. Seorang Gembala janganlah terus menghukum dengan belajar menurut (Mat 7:1-7; Yoh 7:53-8:11), b. Seorang gembala harus tau mengampuni orang lain, c. Seorang Gembala tidak boleh fokus terhadap bisikan-bisikan, d. seorang gembala harus bisa mendengarkan orang lain; ${ }^{22}$ Ketiga, Seorang Gembala harus rajin keluar, tidak berdiam diri melainkan akan memperhatikan keluar karena banyak jiwa-jiwa yang membutuhkan terlebih kepada warga Gereja; Keempat, seorang Gembala tidak usah seorang psikolog. ${ }^{23}$ Jadi, yang menjadi perbedaan sifat Gembala Sidang dengan spiritualias Gembala Sidang, yaitu: berbicara tentang sifat adalah bagaimana seharusnya menjadi Gembala Sidang yang baik, yang dapat memberikan pengaruh dan pertolongan bagi warga Gereja, terlihat bagaimana ia mengasihi orang-orang yang ia pimpin. Sedangkan spiritualitas Gembala Sidang merupakan kehidupan rohani atau hubungannya secara pribadi dengan Allah yang dapat dilihat oleh orang lain dan dapat menjadi teladan bagi kehidupan iman mereka kepada Allah.

\section{Kepemimpinan Gembala Sidang}

Gereja yang sehat dan bertumbuh adalah seorang Gembala Sidang yang menganut cara berpikir serba mungkin dan yang kepemimpinan dinamisnya digunakan untuk mempengaruhi seluruh gereja supaya bekerja bagi pertumbuhan. ${ }^{24}$ Pertama, Kewibawaan Gembala, jenis kasih yang dimiliki jemaat dalam gereja bertumbuh terhadap Gembala Sidang mereka membawa beberapa implikasi yang tidak selalu dapat disadari pada permulaannya. Salah satunya adalah bahwa Gembala Sidang akhirnya memiliki wibawa yang besar. Kedua, Kelanggengan gembala sidang, prinsip kelanggengan ini tidak hanya berlaku bagi Gembala

21 Ibid.

${ }^{22}$ Bons-Storm. M, Apakah Penggembalaan Itu? (Jakarta: Gunung Mulia, 2014), 27.

${ }^{23}$ Ibid

${ }^{24}$ C. Peter Wagner, Gereja Saudara Dapat Bertumbuh (Malang: Gandum Mas, 1990), 59. 
Sidang senior dalam gereja yang banyak stafnya. Jika staf dibangun atas dasar karunia-karunia rohani dan panggilan untuk setiap posisi tertentu, staf ini akan merupakan staf yang kuat. Ketiga, Kepemimpinan Gembala Sidang, kewibawaan Gembala Sidang yang diperoleh melalui hubungan kasih dengan keluarga Allah, adalah suatu unsur penting bagi pertumbuhan. ${ }^{25}$

\section{Tujuan Pembinaan Warga Gereja}

Tujuan pembinaann warga Gereja salah satunya adalah supaya jemaat dapat berkembang dari penegasan tentang Allah yang diperkenalkan melalui Kristus dalam Alkitab. Menurut Lawrence O. Richads mengatakan bahwa pembinaan warga Gereja hanya dapat diketahui ketika terlebih dahulu memahami apa tujuan sebuah Gereja (that the formation of members of the Church can only be known when first understanding what the purpose of a Church is).$^{26}$ Dimana tujuan sebuah Gereja yaitu mencapai keserupaan dengan Kristus, dalam hal sifat, nilai, motif, sikap serta pemahaman bisa terwujud. Maka spiritualitas seorang Gembala Sidang menjadi implikasi keteladanan dalam melaksanakan PWG. Menurut Robert W. Pazmino mengatakan: tujuan pembinaan di Gereja erat hubungannya dengan lima tugas utama Gereja, yaitu: proclamation (kerygma), community formation (koinonia) service (diakonia), advocacy (prophetia), dan worship (liturgia). ${ }^{27}$ Jadi Pazmino menyampaikan bahwa tujuan dari PWG yaitu menyampaikan kebenaran Kristen dan mengaitkannya dengan kehidupan orang percaya. Dengan pengetahuan Alkitab tentang Yesus Kristus dan aspek pengalaman Kristen bersama dengan Yesus Kristus.

Sedangkan menurut Andar Ismail, tujuan pembinaan jemaat adalah untuk memperlengkapi orang-orang kudus bagi pekerjaan pelayanan, bagi pembangunan tubuh Kristus (Ef 4:12), membelajarkan orang dewasa seumur hidup sesuai dengan kepenuhan Kristus (Ef 4:13). PWG dilaksanakan agar setiap orang baik dewasa, remaja, anak-anak menjadi bagian integral dalam seluruh tubuh yang rapi tersusun dan diikat menjadi satu oleh pelayanan bagiannya, sesuai dengan kadar pekerjaan tiap-tiap anggota menerima pertumbuhannya dan membangun dirinya dalam kasih (Ef 4:16). ${ }^{28} \mathrm{Jadi}$, untuk mencapai sebuah tujuan PWG dalam mengimplikasikan keteladanan Spiritulitas Gembala Sidang maka dapat berhasil untuk jemaat mengalami pertumbuhan iman dalam Kristus.

25 Ibid.

${ }^{26}$ Lawrence O. Richards, A Theology of Christian Education (New York: Hill Book Company, 1975), 22.

${ }^{27}$ Robert W. Pazmino, God Our Teacher (Grand Rapids, Michigan: Baker Akademic, 1992), 114.

${ }^{28}$ Andar Ismail, Selamat Natal - 33 Renungan Tentang Natal (Jakarta: BPK Gunung Mulia, 1997), 765.

168 | Copyright $@$ 2021, CARAKA, ISSN 2722-1407 (Cetak), 2722-1393 (Online) 
Tugas pembinaan warga gereja lebih banyak mengarah pada pengajaran dengan upaya memperlengkapi Warga Gereja dengan tugas dan panggilannya di tengah-tengah dunia dan masyarakat dimana dia berada dengan segala apa yang ia miliki. ${ }^{29}$

\section{Isi dari Pengajaran dalam Pembinaan Warga Gereja (PWG)}

Secara teologis panggilan Gereja yang sering kita kenal antara lain ialah beribadah, bersekutu, pemberitaan, mengajar, melayani, meneguhkan, bersaksi (Lirturgia, Koinonia, Kerygma, Didache, Diakonia, Profeteia, dan Marturia). Nah, dalam melakukan pelayanan PWG maka gembala sidang menjadi sorotan untuk melaksanakannya. Gembala Sidang yang benar maka memiliki spiritualitas yang baik sehingga menjadi contoh teladan bagi orangorang yang akan dilayani dalam pembinaan warga Gereja. Karena PWG adalah usaha untuk membina warga gereja menjadi lebih baik dari sebelumnya yang berpusat pada Kristus Tuhan, dan alkitab sebagai pedoman penuntunnya dan merupakan proses untuk menghubungkan jemaat dengan Firman Tuhan melalui, pembinaan, Pembimbingan dan pengajaran yang mendewasakan dalam Kristus melalui kuasa Roh Kudus tidak dengan sembarangan.

Tugas penguatan keyakinan iman Kristen, Gembala menyiapkan jemaat untuk mampu memahami keyakinan iman Kristenya sehingga warga gereja mampu mendemonstrasikannya dalam kehidupan sehari-hari. Penenakan pada pendalaman pemahaman teologi dan Alkitab sangat penting dalam pembentukan spiritualitas. Sebagai contoh pada masa reformasi gereja, tindakan praktis warga gereja mengalami masalah. Faktornya adalah pemahaman yang salah akan keyakinan iman Kristen. Itu sebabnya para reformator menekankan pada Sola Scriptura, sebab dengan kembali pada pemahan teologi Alkitabiah pola pikir dan tindakan praktis Warga Gereja pada masa itu dapat mengalami perubahan. ${ }^{30}$

\section{Pendekatan Pembinaan Warga Gereja (PWG)}

Ada bentuk-bentuk pendekatan dalam PWG, yaitu: Pertama, bentuk pengajaran agama (didache atau religious instruction. Hal ini adalah pengajaran doktrin iman Kristen. Kedua, bentuk persekutuan (koinonia: fellowship). Penekanan di sini adalah interaksi dinamis di antara sesama anggota (1 Pet. 2:9-10, Kol. 3:16). Dalam persekutuan warga jemaat, flesibilitas sangat ditonjolkan. Ketiga, bentuk pengembangan spiritual (spiritual development). Pendekatan ini bertitik tolak dari asumsi bahwa manusia berkembang di sepanjang hidupnya

${ }^{29}$ Suharto Prodjowijono, Manajemen Gereja: Sebiah Alternatif (Jakartya: BPK Gunung Mulia, 2008), 30.

${ }^{30}$ Lenda Dabora J F Sagala, “Gereja Menghadapi Perubahan Sosial," Evangelikal: Jurnal Teologi Injili dan Pembinaan Warga Jemaat 4, no. 2 (2020): 170.

169 | Copyright $\odot$ 2021, CARAKA, ISSN 2722-1407 (Cetak), 2722-1393 (Online) 
(life span development). Dalam hal ini, jemaat dibekali agar mereka dapat menghadapi masalah-masalah yang terjadi dalam hidup dengan tetap menjaga iman yang benar. ${ }^{31}$

Keempat, bentuk pembebasan (liberation). Pendekatan ini bertitik tolak dari pemahaman bahwa peserta didik berada dalam situasi tertawaan atau terkungkung oleh berbagai masalah. Dalam hal ini gereja harus berperan untuk membantu jemaat dalam kondisi tersebut agar mengalami kebebasan dalam arti bebas untuk berpikir, berbicara, mengambil keputusan serta bebas dari kebutaan. Hal ini sesuai dengan teladan Yesus bahwa Ia memberi perhatian pada orang yang tertindas (Luk. 4:18-19).

Kelima, kegiatan penafsiran atau membangun pengertian atau makna (interpretation). Pendekatan ini bertitik tolak dari keyakinan bahwa gereja terpanggil untuk mengemban tugas kenabian atau profetis. Dalam kegiatan belajar, Pembina mengajak anggota kelompok untuk peka terhadap tanda-tanda zaman. Mereka membaca dan mempercakapkannya dengan teliti agar dapat memetik maknanya dalam kehidupan pribadi, keluarga, Gereja dan masyarakat. Aktifitas belajar menekankan dialog antara firman tertulis (teks) dan konteks. Untuk itu konteks masyarakat dan budaya harus dipahami dengan baik.

\section{Spiritualitas Gembala Sidang Sebagai Implikasi Keteladanan dalam Pembinaan Warga} Gereja (PWG)

\section{Hakikat Pembinaan Warga Gereja}

Istilah pembinaan dalam bahasa Inggris, yaitu: Nurture yang berarti "memberikan makan" (to feed), memperkaya (to nourish), membesarkan (to bring up), mendidik (to educate) dan melatih (to train). Pembinaan dapat diartikan sebagai "proses, perbuatan, cara membina; pembaharuan, penyempurnaan; usaha, tindakan dan kegiatan dilakukan secara berdaya guna untuk memperoleh hasil yang baik. Warga Gereja dalam bahasa Yunani "laikoi" yang berarti semua anggota dalam tubuh Kristus yaitu Gereja secara rohani yang telah menerima Kristus sebagai Juruselamat. Dengan demikian Gereja merupakan suatu kesatuan dari semua orang mulai dari anak-anak sampai lanjut usia. Jadi, dapat disimpulkan bahwa Pembinaan Warga Gereja (PWG) adalah pembinaan yang berpusat pada pengajaran tentang Kristus dan Alkitab sebagai dasar pengajarannya.

Penulis dapat melihat hakikat pembinaan warga Gereja itu sendiri dapat dipahami secara sederhana bahwa: Pertama, merupakan perintah langsung oleh Tuhan Yesus yang terdapat dalam keempat Injil, yang lebih mencolok yaitu dalam dalam tulisan Matius 28:18-20 yang disebut dengan Amanat Agung. Dimana Yesus mengharapkan supaya Gereja-Nya harus

31 Riniwati Riniwati, "Bentuk Dan Strategi Pembinaan Warga Jemaat Dewasa," Prosiding Seminar Nasional Pendidikan Agama Kristen STT Simpson Tahun 2016 Tema: Strategi Pembinaan Jemaat Untuk Meningkatkan Kehidupan Jemaat, no. April (2016): 6. 
menjadi Gereja pengajaran;. Kedua, dilihat dari teladan jemaat mula-mula dalam Kisah Para Rasul 2:42-47. Awal mula berdirinya sebuah Gereja pada hari Pentakosta, jemaat menjunjung sekali pengajaran. Dimana ada dalam tulisan Pemazmur yang berkata: "Sepeti ada tertulis: "Tidak ada yang benar, seorang pun tidak. Tidak ada seorang pun yang berakal budi, tidak ada seorang pun yang mencari Allah. Semua orang telah menyeleweng, mereka semua tidak berguna, tidak ada yang berbuat baik, seorang pun tidak". ${ }^{32}$

\section{Spiritualitas Gembala Sidang Sebagai Teladan}

Seorang Gembala Sidang yang menjadi pemimpin rohani, harus dapat diteladani melalui sikap hidup dan perkataan karena kehidupan umat Kristiani selalu disorot dalam segala arah. Gembala Sidang sebagai pemimpin harus mampu menjadi teladan bagi jemaat sebagai murid yang diajar, dididik dan dibimbing. Jika demikian gembala sidang yang berperan sebagai seorang pemimpin yang mengimplikasikan imannya harus mampu menjadi contoh kepada jemaat dalam segala aspek kehidupannya. ${ }^{33}$ Gembala yang baik akan memberikan teladan yang sama seperti sang Gembala yang Agung Yesus Kristus dimana dia tidak pernah mencari keuntungan antara satu dengan yang lannya melainkan menanamkan sikap saling melayani dan memiliki tanggung jawab yang besar untuk misi pembinaan warga Gereja, serta pelayanan didalam atau diluar Gereja.

Seorang Gembala Sidang tidak boleh membeda-bedakan orang lain. Ellen G White, mengatakan bahwa: dalam semua pengajaran yang benar, unsur pribadi sangat penting. Kristus dalam pengajaran-Nya memperlakukan orang secara pribadi. Ia mendidik dua belas orang murid-Nya melalui pergaulan dan kontak pribadi. Sering sekali secara Ia menyampaikan ajaran-Nya yang sangat berharga kepada seorang pendengar-Nya. Ia membuka harta-Nya yang termahal; karena para pendengar ini Ia melihat ada-Nya hati yang mau dipengaruhi, pikiran yang terbuka, roh yang suka menerima. Bahkan orang banyak yang berbondong-bondong mengikuti langkah-Nya, Kristus tidak membeda-bedakan orang disekitar-Nya. ${ }^{34}$

\section{Gembala Sidang Sebagai Pengajar Untuk Pertumbuhan Iman Jemaat}

Tujuan pembinaan supaya Jemaat dapat mengalami pertumbuhan iman. ${ }^{35}$ Dilihat dari peran Gembala dalam Surat 1 Petrus 4:11 berbicara mengenai Gembala dalam karunia mengajar dan melayani. ${ }^{36}$ Makna peran Gembala memiliki pengaruh dalam tingkat

32 David Eko Setiawan and Dwiati Yulianingsih, "Signifikansi Salib Bagi Kehidupan Manusia Dalam Teologi Paulus," FIDEI: Jurnal Teologi Sistematika dan Praktika 2, no. 2 (2019): 227.

33 Telaumbanua, "Peran Gembala Sidang Sebagai Pendidik Dalam Pertumbuhan Rohani Jemaat."

${ }^{34}$ Ellen G White, Membina Pendidikan Sejati (Bandung: Indonesia Publishing House, 2005), 216-217.

${ }^{35}$ Riniwati, 6.

${ }^{36}$ Merilyn Kunz dan Catherine Scheli, $1 \& 2$ Petrus (Bandung: Yayasan Kalam Hidup, 2005$), 9$. 171 | Copyright $\odot$ 2021, CARAKA, ISSN 2722-1407 (Cetak), 2722-1393 (Online) 
pertumbuhan kerohanian jemaat dengan cara mengajar dan melayani, dalam hal ini maka penulis akan memberikan pandangan para ahli sehubungan dengan peran Gembala. Ada dua karunia seorang Gembala, yaitu: Karunia Berbicara dan Karunia melayani. ${ }^{37}$ Hal penting ketika spiritualitas Gembala Sidang yang baik terlihat dari karakternya. Dapat belajar melalui Injil, yaitu Yesus ditampilkan menjadi pengajar yang luar biasa. Maka Gembala Sidang dapat meneladani Yesus yang sangat kreatif dalam mengajar. Dimana dapat dilihat melalui perumpamaan-perumpamaan yang diambil dari kehidupan sehari-hari untuk menjelaskan kebenaran Kerajaan Allah. Tidak salah jika orang yang percaya mengungkapkan bahwa Yesus sebagai pengajar yang Agung. ${ }^{38}$

\section{Spiritualitas Gembala Sidang Sebagi Perwujudan Karakter Kristus}

Dari pembahasan diatas tampak bahwa spiritualitas Gembala Sidang adalah perwujudan dari karakter Kristus. Dalam berbagai situasi dan tantangan sebagai Gembala Sidang harus memiliki kemampuan untuk menghayati spiritualitasnya. Ada banyak Gembala Sidang yang sekarang ini yang spiritualitasnya merosot. Yang menjadi harapan terhadap Gembala Sidang adalah sebuah keteladanan seorang hamba Kristus.

Adapun implikasi dari hal tersebut adalah sebagai berikut: Pertama, sulit akhir-akhir ini didapati Gembala Sidang yang dapat dipercaya oleh warga Gereja. Kedua, penggembalaan yang tidak benar akan menghasilkan warga Gereja yang tidak benar pula terlebih dalam pembinaan warga Gereja. Ketiga, Gereja akan kehilangan pengaruh atau tidak memberikan dampak positif bagi masyarakat luas. Gereja yang dimaksud di sini adalah persekutuan orangorang yang telah percaya kepada Kristus dan yang telah dipanggil. ${ }^{39}$

Seorang Gembala yang sejati mengasihi domba-dombanya dan memberi hidupnya bagi mereka. ${ }^{40}$ Dengan spiritualitas yang bisa diteladani oleh warga Gereja dan terpancar kasih didalamnya. Sehingga membangun domba atau jemaat untuk meningkatkan kerohanian iman mereka terhadap Firman Allah. Dapat menunjukkan sikap terhadap orang lain dengan situasi dan kondisi seseorang tersebut. Sikap gembala terhadap dombanya/jemaat dalam Gereja hendaklah seorang hamba Tuhan hidup penuh dengan pelayanan yang Tuhan kehendaki, makna spiritualitas Gembala Sidang serta kepribadian itu dapat menentukan apakah orang tersebut dapat menjadi pemimpin yang baik atau menjadi pemimpin yang buruk.

37 LB. Dit. Jenifer W. Silas Flyn, 19 Karunia Roh Yang Mana Yang Anda Pilih? Apakah Anda Menggunakannya? (Batam: Gospel Press, 2001), 56.

38 David Eko Setiawan, "Dampak Injil Bagi Transformasi Spiritual Dan Sosial," BIA': Jurnal Teologi dan Pendidikan Kristen Kontekstual 2, no. 1 (2019): 83-93.

${ }^{39}$ Setiawan and Ishariyono, 116.

${ }^{40}$ Dag Heward-Mills, Seni Menggembalakan (Jakarta: Terjemahan baru lembaga Indonesia, 2009), 25. 172 | Copyright@ 2021, CARAKA, ISSN 2722-1407 (Cetak), 2722-1393 (Online) 


\section{KESIMPULAN}

Spiritualitas seorang Gembala Sidang sangat menentukan dalam pertumbuhan warga Gereja. Spiritualitas Gembala Sidang menetukan keberhasilan Pembinaan Warga Gereja. Gembala Sidang yang benar maka akan menghasilkan warga Gereja yang baik juga. Menjadi Gembala Sidang harus memiliki nilai, makna dan tujuan yang sesuai dengan kehendak Tuhan. Seiring dengan adanya penilaian negatif kepada Gembala Sidang, maka menjadi Gembala Sidang harus menghidupi spiritualitasnya. Jika hamba Tuhan tidak menghidupi spiritualitasnya, maka akan berimplikasi akan menemukan hamba Tuhan yang tidak dapat dipercaya. Selain itu akan berimplikasi kepada Warga Gereja. Gembala Sidang yang tidak baik akan menghasilkan warga Gereja yang tidak baik juga. Kemudian Gereja akan kehilangan pengaruh positif bagi masyarakat luas.

\section{DAFTAR PUSTAKA}

Anggu, Peter. Etika Penggembalaan. Makassar: STT Jaffray, 2003.

Cowles, Robert. Gembala Sidang. 5th ed. Bandung: Yayasan Kalam Hidup, 2000.

Dermot, G. R. Mc. Mengenali12 Tanda Kerohanian Sejati. Edited by Terj. Suryadi. Yogyakarta, 1995.

Djadi, Jermia. "Spiritualitas Seorang Pelayan Kritus.” Jaffray 10, No. 1 (2012): 110-117. Elrath, Billy Matheas. Ensiklopedia Alkitab Praktis. Bandung: Yayasan Kalam Hidup, 1978. Flyn, LB. Dit. Jenifer W. Silas. 19 Karunia Roh Yang Mana Yang Anda Pilih? Apakah Anda Menggunakannya? Batam: Gospel Press, 2001.

Heward-Mills, Dag. Seni Menggembalakan. Jakarta: Terjemahan baru lembaga Indonesia, 2009.

Howard, Rice. Management Umat. Bandung: Yayasan Kalam Hidup, 2006.

Hutahaean, Hasahatan, Bonnarty Steven Silalahi, and Linda Zenita Simanjuntak. "Spiritualitas Pandemik: Tinjauan Fenomenologi Ibadah Di Rumah.” Evangelikal: Jurnal Teologi Injili dan Pembinaan Warga Jemaat 4, no. 2 (2020): 234.

Iqaq, E. W. "Pemimpin Sebagai Gembala." JURNAL JAFFRAY 12, No.1 (2014): 27-34.

Ismail, Andar. Selamat Natal - 33 Renungan Tentang Natal. Jakarta: BPK Gunung Mulia, 1997.

M, Bons-Storm. Apakah Penggembalaan Itu? Jakarta: Gunung Mulia, 2014.

Nugroho, Fibry Jati. “GEREJA DAN KEMISKINAN :” 3 (2019): 100-112.

Pailang, H. S. I. B. P. "Membangun Spiritual Remaja Masa Kini Berdasarkan Amsal 22 : 6." Jaffray 10, No. 1 (2012): 59-86.

Pazmino, Robert W. God Our Teacher. Grand Rapids, Michigan: Baker Akademic, 1992.

Prodjowijono, Suharto. Manajemen Gereja: Sebiah Alternatif. Jakartya: BPK Gunung Mulia, 2008.

Purwodarminto, WJS. Kamus Umum Bahasa Indonesia. Jakarta: Yayasan Kalam Hidup, 1992.

Richards, Lawrence O. A Theology of Christian Education. New York: Hill Book Company, 1975.

Riniwati, Riniwati. "Bentuk Dan Strategi Pembinaan Warga Jemaat Dewasa.” Prosiding Seminar Nasional Pendidikan Agama Kristen STT Simpson Tahun 2016 Tema: Strategi Pembinaan Jemaat Untuk Meningkatkan Kehidupan Jemaat, no. April (2016): 1-13.

Sagala, Lenda Dabora J F. "Gereja Menghadapi Perubahan Sosial." Evangelikal: Jurnal Teologi Injili dan Pembinaan Warga Jemaat 4, no. 2 (2020): 167-174.

Sari, Milya, and Asmendri. "Penelitian Kepustakaan (Library Research) Dalam Penelitian Pendidikan IPA." Penelitian Kepustakaan (Library Research) dalam Penelitian 
Pendidikan IPA 2, no. 1 (2018): 15.

Scheli, Merilyn Kunz dan Catherine. 1\&2 Petrus. Bandung: Yayasan Kalam Hidup, 2005.

Setiawan, David Eko. "Dampak Injil Bagi Transformasi Spiritual Dan Sosial." BIA': Jurnal Teologi dan Pendidikan Kristen Kontekstual 2, no. 1 (2019): 83-93.

Setiawan, David Eko, and Anton Ishariyono. "Hakikat Spiritualitas Pelayan Kristus Dan Implikasinyabagi Hamba Tuhan Masa Kini" 2, no. 2 (2020): 116-128.

Setiawan, David Eko, and Dwiati Yulianingsih. "Signifikansi Salib Bagi Kehidupan Manusia

Dalam Teologi Paulus." FIDEI: Jurnal Teologi Sistematika dan Praktika 2, no. 2 (2019): 227-246.

Sopater, Sularso. Kepemimpinan Dan Pembinaan Warga Gereja. Jakarta: Yayasan Wahana Dharma, 1998.

Telaumbanua, Arozatulo. "Peran Gembala Sidang Sebagai Pendidik Dalam Pertumbuhan

Rohani Jemaat.” FIDEI: Jurnal Teologi Sistematika dan Praktika 2, no. 2 (2019): 362387.

Wagner, C. Peter. Gereja Saudara Dapat Bertumbuh. Malang: Gandum Mas, 1990.

White, Ellen G. Membina Pendidikan Sejati. Bandung: Indonesia Publishing House, 2005.

Wibisana, Agung. Crist Centered Church. Bandung: Gereja perpustakaan Kristus, 2016.

Kamus Besar Bahasa Indonesia,. Jakarta: Departemen Pendidikan Nasional, 2008. 